\title{
The probability of occurrence of disperser and pollinator birds in urban riparian forests
}

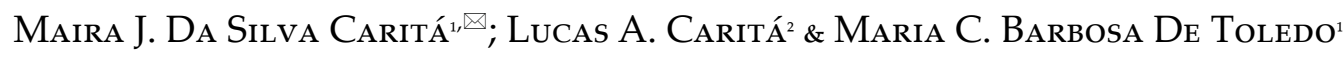 \\ ${ }^{1}$ Universidade de Taubaté (UNITAU), Taubaté, São Paulo, Brasil. ${ }^{2}$ Instituto Federal de Educação, Ciência e Tecnologia de \\ São Paulo (IFSP), São José dos Campos, São Paulo, Brasil.
}

\begin{abstract}
Aвstract. Riparian forests are important for their ecological function and provision of services regarding the maintenance of water resources and wild fauna. Paradoxically, it is one of the ecosystems that suffer most from anthropization, especially urbanization. Thus, our objective was to compare the probability of occurrence of pollinating and dispersing species in two areas of riparian forest, where the periurban fragment is inserted in an area with patches of forest remnants and the urban fragment, an area of forest remnant located in a heavily constructed region. From the results obtained, we note that the riparian forest area considered preserved had the highest occurrence of dispersers, while the area inserted in the urban matrix had the highest occurrence of pollinators. In this way, it was possible to observe that the most preserved area showed greater equality between the groups, with a greater number of dispersers. Still, riparian forest isolated by strong urbanization showed that dispersers had a low frequency of occurrence, an essential function in the renewal and continuity of riparian forest in the future.
\end{abstract}

[Keywords: urbanization, dispersers, pollinators, environmental sciences, functional groups]

\begin{abstract}
RESUMEN. La probabilidad de aparición de aves polinizadoras y dispersoras en bosques ribereños urbanos. Los bosques ribereños son importantes por su función ecológica y por los servicios que prestan en relación con el mantenimiento de los recursos hídricos y la fauna silvestre. Asimismo, constituyen uno de los ecosistemas que más sufren la antropización, especialmente en las áreas urbanas. Nuestro objetivo fue comparar la probabilidad de ocurrencia de especies de aves polinizadoras y dispersoras en dos áreas de bosque de ribera ubicadas en São José dos Campos, São Paulo, Brasil. Se registraron la aves mediante puntos de conteo en un fragmento ribereño periurbano y en un fragmento urbano. Los resultados obtenidos muestran que el fragmento ribereño tuvo la mayor ocurrencia de dispersores, mientras que el fragmento urbano tuvo la mayor ocurrencia de polinizadores. De esta forma se pudo observar que el área más preservada mostró mayor igualdad entre ambos grupos, con mayor número de dispersores. Por otro lado, el bosque de ribera aislado por una fuerte urbanización mostró que los dispersores presentaban baja frecuencia de ocurrencia, una función muy importante en la renovación y la continuidad del bosque de ribera en el futuro.
\end{abstract}

[Palabras clave: urbanización, dispersores, polinizadores, ciencias ambientales, grupos funcionales]

\section{INTRODUCTION}

Human interference significantly affects bird species that live in natural ecosystems (Marini and Garcia 2005; Tella et al. 2020), including riparian forests, which are one of the most degraded ecosystems (Ferreira and Dias 2004). Urbanization is the transformation of soil, which houses natural biota, in anthropic environments (Angeoletto and Santos 2015). The urban landscape is usually fragmented into a mosaic of varied environments, presenting a different plant structure and floristic composition than that originally present (Mendonça and Anjos 2005). However, the urban landscape can offer different conditions and resources to be used by fauna (Fonseca et al. 2012). Occasionally, when a community is disturbed, an alternative stable state is established. This happens when the disturbance occurs to the point of changes in species composition and population abundance in this community, leading to a new structure resistant to alteration (Ricklefs and Relyea 2018). The effects of these changes can be observed in different ways in birds, as species that were favored with such changes and expanded their populations have already been found, as well as extinct others (Marini and Garcia 2005). Thus, it is important to understand that small variations in the environmental aspect can promote changes in the community, changing the distribution and abundance of several species (Ricklefs and Relyea 2018). One way to qualify and quantify the effect of an environmental change is the use of bioindicators, which, in general, consists 
of using living beings, plants or animals, to identify certain environmental changes (Cetesb 2020). In the context of urbanization, the decrease in bird species richness and the increase in the abundance of species tolerant of human coexistence can be used to identify anthropization (Butterfield et al. 1995).

Usually, birds were proposed, evaluated or used as indicator species for various environmental parameters, responding to the conditions of ecosystems that incorporate forests, pastures, including disturbances and processes such as urban expansion (Chambers 2008; Mekonen 2017). Bioindicators are often adopted in research and environmental management as a diagnostic tool. That is, indicator species are tasked with representing the status of the environment or serving as an equivalent for a larger number of species and can provide information on the condition and modification of the environment (Nguyen 2007; Mekonen 2017). Birds have great food diversification and, due to this, are responsible for several functions, such as seed dispersal, pollination, population control, among others (Naime 2011). Species with the same ecological needs being classified into functional groups become an important assessment mechanism in relation to birds' responses to environmental influences (Bennet et al. 2004; Uezu et al. 2005; Steinitz et al. 2006). The use of disperser and pollinator functional groups of birds as bioindicators of environmental condition is relevant because the urbanization of an area can lead to fragmentation and isolation of native areas, reducing the availability of resources (Silva 2010). Consequently, both isolation and lack of resources can interfere with the processes of continuity in the remaining areas, mainly through the reduction of dispersing and pollinating species (Naime 2011).

Our objective was to compare the probability of occurrence of pollinating and dispersing species in two areas of riparian forest, one included in a permeable urban matrix and the other inserted in a strongly urbanized impermeable matrix. Based on the theoretical framework above, this study predicted that isolated riparian forests in heavily urbanized areas change the composition and structure of the bird community of the functional groups of pollinators and dispersers, which are important for the maintenance of the forest for as long as possible.

\section{Material And Methods}

\section{Study site}

The study was conducted in the city of São José dos Campos, São Paulo, Brazil. The city is located on the Atlantic plateau and is included in the natural subdivisions, defined by distinct morphological characteristics: Serra da Mantiqueira, Médio Vale do Paraíba and Planalto de Paraitinga. It is established in the Atlantic Forest biome, with native vegetation on the slopes, spurs and ridge points of Serra da Mantiqueira.

Two areas of riparian forest were chosen, the periurban fragment located in the City Park 'Roberto Burle Marx', on the banks of the Paraíba do Sul River, an area under recovery with patches of forest remnants, with an area of $~ 950000 \mathrm{~m}^{2}$. The urban fragment, an area of forest remnant that presents the source and extension of the Senhorinha stream, located in the Bosque dos Ipês neighborhood, a heavily built region without the presence of wooded green areas, with an area of $\sim 300000 \mathrm{~m}^{2}$. This study was conducted in an area of $\sim 250000 \mathrm{~m}^{2}$ for each site.

To determine the observation points, a sampling method with marking of fixed points equidistant about $200 \mathrm{~m}$ in the vicinity of the riparian forest of the study areas was used. Eight points count were selected for each study area. The study areas and the coordinates of the observation points are highlighted in Figure 1 . The visits to the sampling areas were conducted in the morning, between 5:30 a.m. and 9:30 a.m., on each day two observation points were visited, totaling 3 hours of observation per day, at each point the permanence time was approximately $1 \mathrm{~h}$ $30 \mathrm{~min}$. As noted, it took 4 days of field work to visit each area, that is, 8 days to perform the procedure in both study areas. After 15 days, this process was repeated, causing each area to be visited twice, throughout the months of study (i.e., there were 16 days of observation per month). Observations of birds species were performed twice a month at each point, nearly every 15 days, from September to December 2020 , resulting in a sample effort of 128 hours (total).

\section{Bioindicators}

The selection of birds species to form a functional group was based on the study 


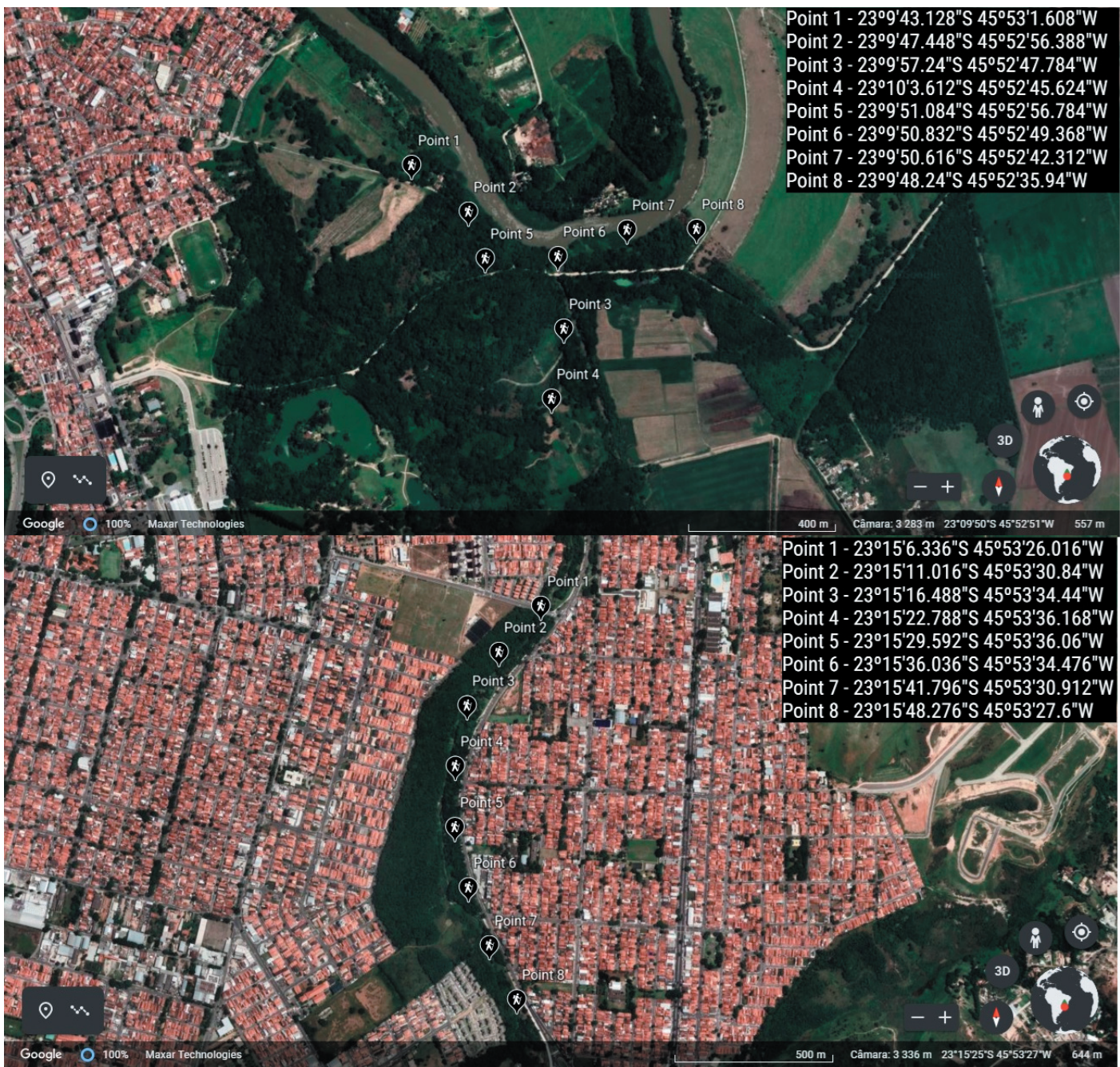

Figure 1. Periurban and urban fragments, respectively, each with 8 observation points and their coordinates.

Figura 1. Fragmentos periurbanos y urbanos, respectivamente, cada uno con 8 puntos de observación y sus coordenadas.

performed by Leveau (2013), composed of bird species that nest in trees, are nectarivores and that feed on fruit. The characteristics of these species are associated with pollination and seed dispersal that promote the propagation of flora species. In addition to this important function, the presence of species that nest in trees denotes the function of shelter for fauna in these urban forest areas. The species chosen by us were selected from a survey performed by Toledo et al. (2012) and Monteiro (2018), who conducted studies of the urban bird community in the region of our study. The selected dispersers were Euphonia chlorotica, Thlypopsis sórdida, Mimus saturninus, Turdus amaurochalinus, Turdus rufiventris, Turdus leucomelas and the selected pollinators were Coereba flaveola, Amazilia láctea, Eupetomena macroura and Phaethornis pretrei.

\section{Data collection}

The selected species are conspicuous in both vocalization and morphology (size and color), which facilitates identification in the field. In addition to the fixed point count method, the playback technique was used. This technique allows the reproduction of birds' songs to be able to attract them, enabling the collection of data and recording of the presence of the species being studied (Boscolo 2002; Meira 2016). Upon reaching the observation point, the observer remained silent for $10 \mathrm{~min}$, after this period, using a Grasep D-G118 loudspeaker, the playback technique was performed, emitting the vocalization of a certain species 3 times and waiting for $2 \mathrm{~min}$ for certificating presence or absence between each call. The procedure was repeated for each of the 10 species. The presences were considered 
through vocalizations and also visually. For observation, Fujinon 400 (8x40) binoculars were used and for photographic records a Canon PowerShot SX400 IS camera.

\section{Data analysis}

For data analysis, presence at each point in at least one of the monthly visits was considered. In each fragment, for each species, in each month, the frequency of observation (FOperiurban fragment and FO-urban fragment) was computed, which consists of the quotient of the number of points where the species of interest is present by the total number of points.

Considering the FO-periurban fragment and FO-urban fragment data, the non-parametric test two-way ANOSIM (Clarke 1993) was performed using the PAST software (Hammer et al. 2001) to compare the similarity between the presence of our selected species in the two study areas, as well as between species. ANOSIM is commonly used for taxon-insample data, where groups are samples that need to be compared (Hammer et al. 2001).

Also, for each species and each month, the quotient between the number of points where presence was registered by the total number of points in each area was calculated. The results were presented in comparative histograms and, using the Bioestat 5.0 software (Ayres et al. 2007), the non-parametric $X^{2}$-Chi-Square test for independent samples was applied, in order to identify significant differences between the data.

To compare the functional groups of interest (pollinators and dispersers), for each point in each area, a quotient was made between the number of species observed in each functional group by the total number of pre-selected species of that same group, for the 4 months studied. This provided the percentage of the presence of the species of interest of the selected functional groups at each point in each area for the months studied. An arithmetic mean between the percentages by points of each area was performed. The performed analysis is assuming that all species composing the biological community are similarly detected, and detectability is constant over space and time. The approach excludes the probability of detection or detectability. The result was plotted on a line graph, for comparison, where pollinators and dispersers of the periurban fragment and urban fragment can be visualized.

\section{Results}

The pollinating species were more observed in the urban fragment and the seed dispersers in the periurban fragment. The two-way ANOSIM was performed for FO-periurban fragment and FO-urban fragment, between the study areas and between species. It was possible to observe that there was a significant difference between periurban fragment and urban fragment $(R=0.20 ; P=0.0038)$. This result shows us that these sites present differences in relation to the frequency of observation of the selected species. When comparing the species, we obtained a highly significant difference $(\mathrm{R}=0.43 ; \mathrm{P}=0.0001)$, that is, there was variation in the frequency of observation between the selected species.

Figure 2 shows the percentage of points where a certain species was observed in each month for both areas, species by species, for each month of study, and the result of the Chi-Square analysis. It can be observed that, in general, the pollinating species were more observed in the urban fragment and the dispersers in the periurban fragment. Turdus leucomelas and T. rufiventris stand out for presenting a high frequency of observation in both study areas and did not show significant differences in any month of study. Turdus amaurocholinus showed a significant difference between the areas in three of the four months studied, being always more observed in the periurban fragment, also E. macroura showed a significant difference between the areas in every month of studies, we can highlight its greater presence in the urban fragment. Amazilia lactica in September had a lower frequency of observation in both study areas and the months with more observations were October and November. Phaethornis pretrei was the least observed hummingbird species during the study period, its observation frequency remained constant in all months in the periurban fragment. In the urban fragment, the highest frequency of observation of this species was in November and the lowest in September and October. When we compare pollinators and dispersers in the study areas, we note that pollinators have a greater presence in the urban fragment except in November. In Figure 3, we can see that the two areas of studies show the same behavior in relation to dispersers, but periurban fragment shows greater favoring of this functional group. 

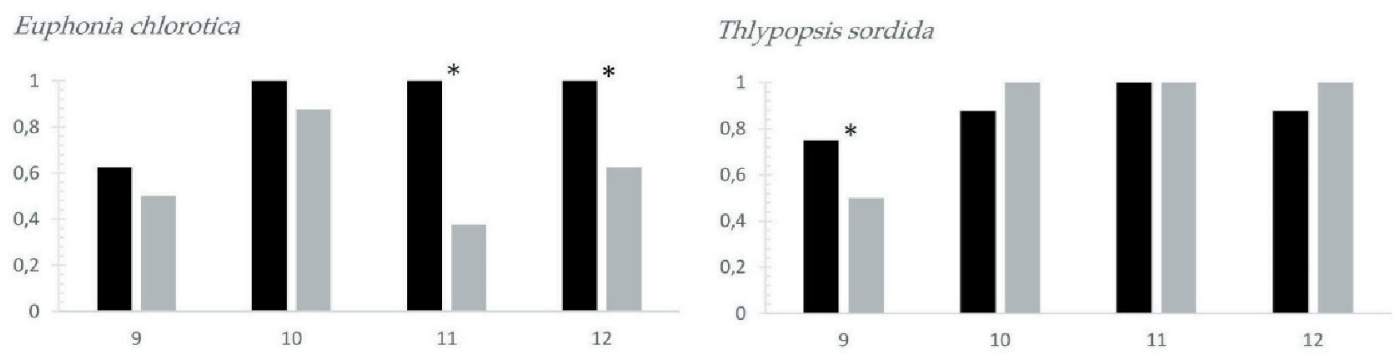

Mimus saturninus

Turdus amaurochalinus
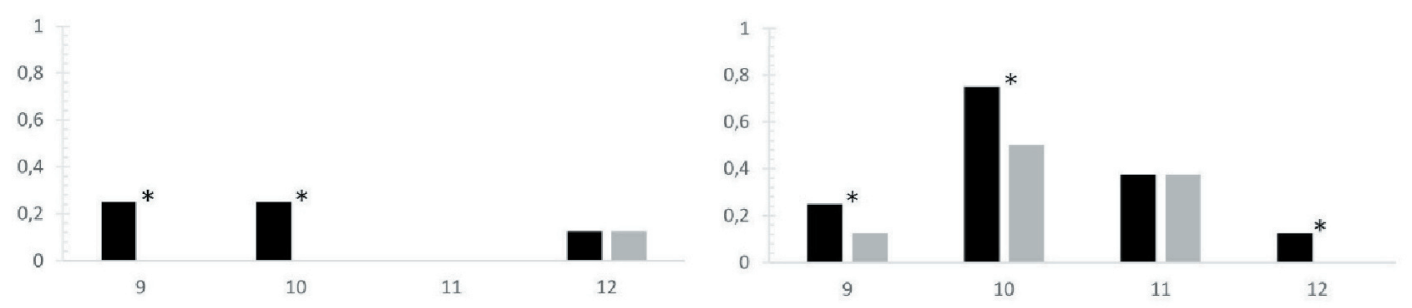

Turdus rufiventris

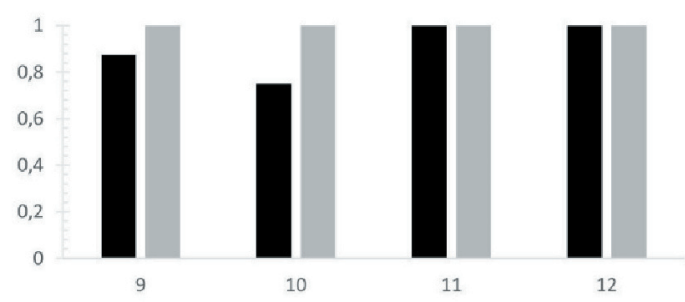

Turdus leucomelas

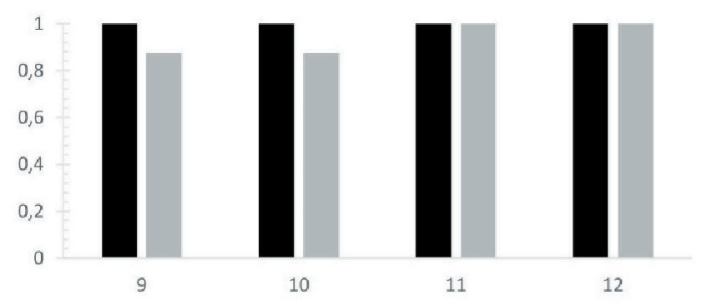

Coereba flaveola

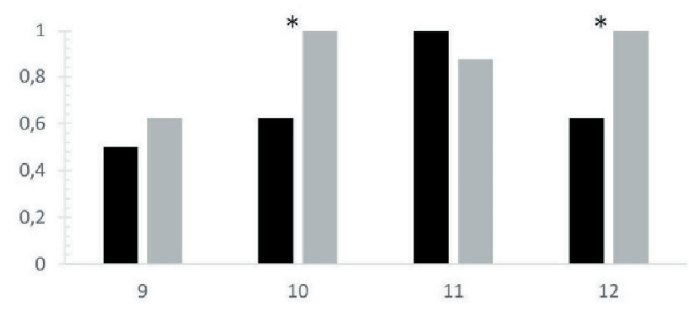

Amazilia láctea

Eupetomena macroura
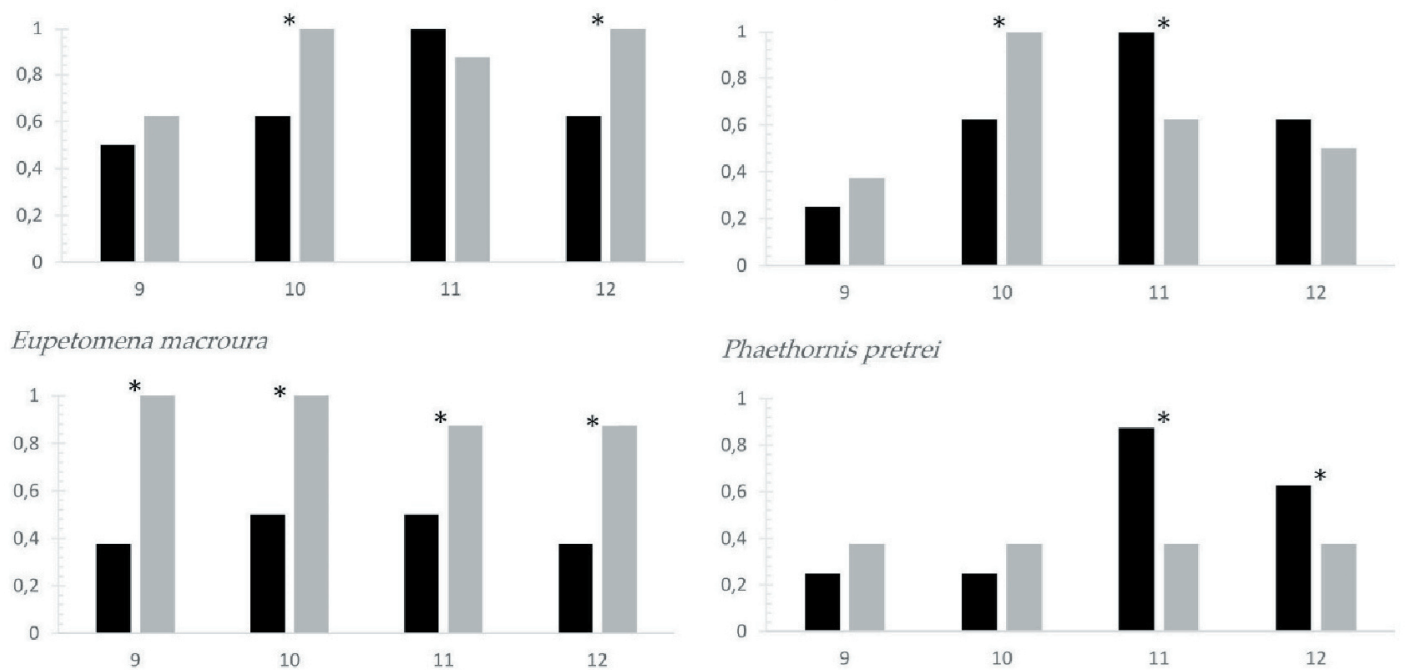

Phaethornis pretrei

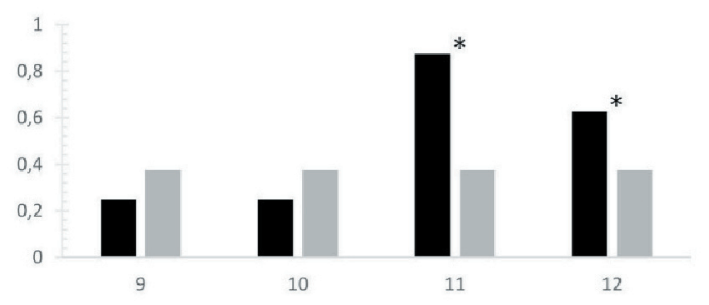

- Periurban Fragment Urban Fragment

Figure 2. Comparison between species in the four months of study in the two areas of interest. The numbers $9,10,11$ and 12 indicate the months September, October, November and December $\left({ }^{*}\right.$ : significant difference by $\left.X^{2}\right)$.

Figura 2. Comparación entre especies en los cuatro meses de estudio en las dos áreas de interés. Los números 9, 10, 11 y 12 indican los meses septiembre, octubre, noviembre y diciembre $\left({ }^{*}\right.$ : diferencia significativa por $\left.X^{2}\right)$. 


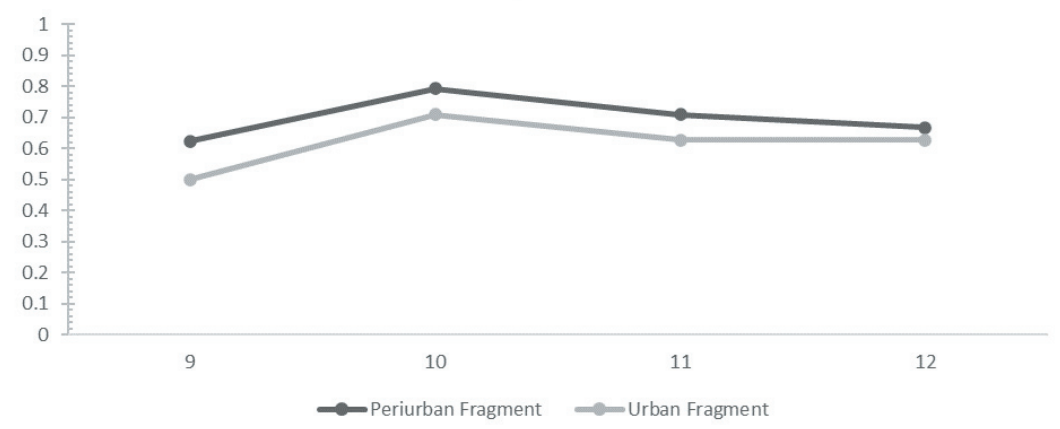

Pollinators

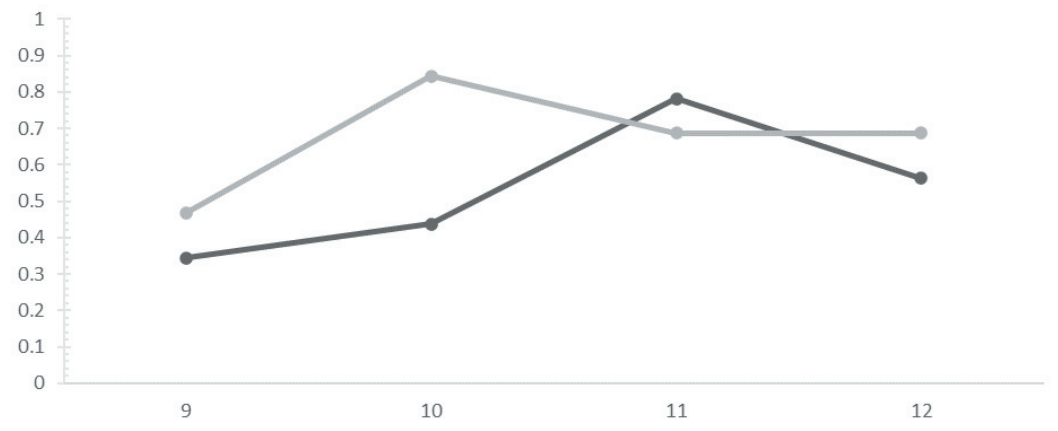

Figure 3. Comparison between periurbanandurbanfragments in relation to seed dispersers and pollinators. The numbers 9, 10, 11 and 12 indicate the months September, October, November and December.

Figura 3. Comparación entre el fragmento periurbano $y$ el fragmento urbano en relación con las aves polinizadoras y dispersoras de semillas. Los números $9,10,11$ y 12 indican los meses de septiembre, octubre, noviembre y diciembre.

\section{Discussion}

Regarding the frequency of occurrence of the species being studied, our results showed that there was a difference between the periurban and urban riparian forest fragments. Urbanized areas, through changes in land use, can promote the loss of species through the shrinkage and fragmentation of the area available for native species (McKinney 2002; Sacco et al. 2015), and simplification of the vertical structure of the vegetation (Marzluff and Ewing 2001; Toledo et al. 2012). The combination of these factors negatively affects habitat quality for animals and tends to intensify with increasing urbanization (Alberti et al. 2001; Sacco et al. 2015).

The results regarding the frequency of occurrence of the species evaluated in the periurban forest remnant (recovery area) and urban (remnant) indicate that the environments suffered and still suffer strong anthropic pressure. Species with generalist habits tends to adapt better to the changes generated by anthropic intervention, since, despite the fragmentation, decrease and alteration of the natural habitat, some urban matrices can complement the availability of resources and habitat necessary for the maintenance of the species considered more resistant and less demanding (Gascon et al.
1999; Santos 2014). Species such as T. leucomelas and T. rufiventris, both dispersers, presented high frequency of occurrence in both study areas. A work performed by Scherer et al. (2007), demonstrated that T. rufiventris was extremely relevant for the maintenance of the dynamic structure of the fragments, due to the ability to move and consume various fruits. Additionally, studies by Corlett (1998), Francisco and Galetti (2002) and Silva et al. (2002) demonstrated that species of the genus Turdus appear among the most important for seed dispersal. Unlike T. leucomelas and T. rufiventris, the species $M$. saturninus and T. amaurochalinus, both omnivorous and dispersers, were poorly observed in both study areas. Non-migratory species that occur sporadically in green areas, can live and breed around cities (Argel-de-Oliveira 1987; Matarazzo-Neuberger 1990; Hofllng and Camargo 1993). Thus, according to Argelde-Oliveira (1995), individuals occasionally observed in urban areas, possibly are born in green areas that disperse in search of a favorable environment, generating a constant flow of these birds, between preserved areas and urban fragments. Considering that omnivorous and generalist species are favored by the presence of the forest edge (Anjos 1990) and by the heterogeneity of vegetation types in altered environments (Anjos 1990; Cândido Jr. 
2000; Aleixo 2001), it is possible to assume that the current characteristics of both the areas studied provide, in whole or in part, both food and reproductive resources that guarantee the permanence of these species in urban green areas (Silva et al. 2014).

Regarding pollinators, our results corroborate other studies that describe nectarivores as explorer species in urban areas. Nectarian species are adept at exploring altered environments, where they can find native and exotic flowers available throughout the year present in various green areas, such as gardens, backyards, parks, squares (Guilherme 2001; Mendonça and Anjos 2005; Toledo and Moreira 2008; Filho and Silveira 2012). Eupetomena macroura is associated with aggressive behavior in territorial defense (Justino et al. 2012; Maruyama et al. 2019) competing with C. flaveola for the same food resource (Calviño-Cancela 2006). Additionally, E. macroura has a diverse diet, being predominantly insectivorous in the reproductive period when protein needs are greater (Moran et al. 2019). The structure of the urban fragment can maintain both floral resources and insect assemblages that live in urban green areas (Lowe et al. 2018; Maruyama et al. 2019). Thus, urban forest areas, which have green areas, can sustain the presence of E. macroura, even in the absence of nectar, due to the food variation of this species. Phaethornis pretei, on the other hand, had greater frequency of occurrence in the periurban fragment. This specialized species is common in natural forest environment and forest edges (Matias et al. 2016; Maruyama et al. 2019), but P. pretei can benefit from the urban matrix as it can occasionally be found among houses in wooded gardens and building nests suspended on roots hidden under bridges (Sick 1997; Willis and Oniki 2003). The A. lactica species also showed a marked variation between the two study areas, with a higher frequency of observation between periurban and urban fragments, depending on the month. This variation is likely associated with the diversity and abundance of plants that provide nectar (Stiles 1981; Cotton 1998; Chupil and Roper 2014). These results corroborate the theory that urban area works as a phylogenetic and phenotypic filter for hummingbirds, as proposed by Puga-Caballero et al. (2020) who comment that urban areas favor hummingbirds of size and large peak of beaks.

In view of the results obtained in the two areas and the low variation between species, homogenization of functional groups is observed (Croci et al. 2008; Aguiar 2015). Biotic homogenization comes from the replacement of natural environments by anthropic environments, leading to a replacement of rare and specialized species by generalist species (Sol et al. 2014; Silva et al. 2016). It is important to highlight that this study covers 4 months of survey in a period of greater activity of birds, the reproductive period, all these results add knowledge of how urbanization influences the fragments that are influenced by the urbanization process.

Acknowledgments. Maira Caritá thanks the CAPES agency for supporting this research. The authors of this article are grateful to the City Hall of São José dos Campos - SP, the public servants Ronaldo Madureira, Elisa Farinha and Luciano Machado and interns Rayres Garcia, Isadora Teixeira, Gabriela Araujo, Deni Biasoli, Ana Velasques, Deyrdre Merlo, Paolla dos Santos and Vivian-dos Santos Faria.

\section{References}

Aguiar, A. G. 2015. As influências da paisagem urbana em grupos funcionais e riqueza de aves. MSc tesis. Instituto de Biociências, Letras e Ciências Exatas, Universidade Estadual Paulista "Júlio de Mesquista Filho", São Paulo, Brasil.

Alberti, M., E. Botsford, and A. Cohen. 2001. Quantifying the urban gradiente: linking urban planning and ecology. In: Marzluff, J., R. Bowman and R. Donnelly. eds. Avian ecology and conservation in na urbanizing world. First edition. Springer, Boston, MA, USA. https://doi.org/10.1007/978-1-4615-1531-9_5.

Aleixo, A. 2001. Conservação da avifauna da floresta Atlântica: efeitos da fragmentação e a importância de florestas secundárias. In J. L. B. Albuquerque, J. F. Cândido Jr., F. Straube and A. L. Roos (eds.). Ornitologia e conservação: da ciência às estratégias. Tubarão, Editora Unisul.

Angeoletto, F., and J. W. M. C. Santos. 2015. Los biólogos brasileños no habitan en el planeta ciudad: por qué es urgente formar ecólogos urbanos. Revista Espaço Acadêmico 14:74-82.

Anjos, L. 1990. Avian Distribution in na Araucaria Forest of Curitiba city (South Brazil). Acta Biologica Paranaense 19: 51-63. https://doi.org/10.5380/abpr.v19i0.776.

Argel-de-Oliveira, M. M. 1987. Obervações preliminares sobre a avifauna da cidade de São Paulo. Bolm CEO 4:6-39.

Argel-de-Oliveira, M. M. 1995. Aves e vegetação em um bairro residencial da cidade de São Paulo (São Paulo, Brasil). Revista Brasileira de Zoologia 12:81-92. https://doi.org/10.1590/S0101-81751995000100011. 
Boscolo, D. 2002. O uso de técnicas de playback no desenvolvimento de um método capaz de atestar a presença ou ausência de aves no interior de fragmentos florestais. Dissertação. Mestrado em Ecologia: Ecossistemas Terrestres e Aquáticos. Universidade de São Paulo, São Paulo, Brasil. Pp. 59.

Butterfield, J., M. L. Luff, M. Baines, and M. D. Eyre. 1995. Carabid beetle communities as indicators of conservation potential in upland forests. Forest Ecology and Management 79:63-77. https://doi.org/10.1016/0378-1127(95)036202.

Calviño-Cancela, M. 2006. Time-activity budgets and behaviour of the Amazilia hummingbird, Amazilia amazilia (Apodiformes: Trochilidae) in an urban environment. Revista de Biología Tropical 54:873-878. https://doi.org/ 10.15517/rbt.v54i3.13684.

Cândido Jr., J. F. 2000. The edge effect in a forest bird Community in Rio Claro, São Paulo State, Brazil. Ararajuba 8: 9-16.

CETESB. Bioindicadores: o uso de bioindicadores vegetais no controle da poluição atmosférica. 2020.

Chambers, S. A. 2008. Birds as environmental indicators: review of literature. First edition. Parks Victoria Technical Series. Parks Victoria, Melbourne, Austrália.

Chupil, H., and J. J. Roper. 2014. Assembleia de beija-flores (Família Trochilidae) em uma região de ecótone no município de Piraquara, Paraná. Atualidades Ornitológicas 177:7-9.

Corlett, R. T. 1998. Frugivory and seed dispersal by vertebrates in the Oriental (Indomalayan) region. Biological Reviews 73:413-448. https://doi.org/10.1017/S0006323198005234.

Cotton, P. A. 1998. Coevolution in na Amazonian hummingbird-plant Community. Ibis 140:639-646. https://doi.org/ 10.1111/j.1474-919X.1998.tb04709.x.

Croci. S., A. Butet, and P. Clergeau. 2008. Does urbanization filter birds on the basis of their biological traits? The Condor 110:223-240. https://doi.org/10.1525/cond.2008.8409.

Ferreira, D. A. C., and H. C. T. Dias. 2004. Situação atual da mata ciliar do Ribeirão São Bartolomeu em Viçosa, MG. Revista Árvore 28:617-623. https://doi.org/10.1590/S0100-67622004000400016.

Filho, J. C. M., and R. V. Silveira. 2012. Composição e estrutura trófica da comunidade de aves de uma área antropizada no oeste do estado de São Paulo. Atualidades Ornitológicas 167:51-58.

Francisco, M. R., and M. Galetti. 2002. Aves como potenciais dispersoras de sementes de Ocotea pulchella (Lauraceae) numa área de vegetação de cerrado do sudeste brasileiro. Revista Brasileira de Botânica 25:11-17. https://doi.org/ $10.1590 /$ S0100-84042002000100003.

Fonseca, V. L. I., D. A. L. Canhos, D. A. Alves, and A. M. Saraiva. 2012. Polinizadores no Brasil - Contribuições e perspectivas para a biodiversidade, uso sustentável, conservação e serviços ambientais. First Edition. Edusp, São Paulo, São Paulo, Brasil.

Gascon, C., T. E. Lovejoy, and R. O. Bierregaard. 1999. Matrix habitat and species persistence in tropical forest remnants. Biology Conservation 91:223-229. https://doi.org/10.1016/S0006-3207(99)00080-4.

Guilherme, E. 2001. Comunidade de aves do Campus e Parque Zoobotânico da Universidade Federal do Acre, Brasil. Revista Sul-Americana de Ornitologia: Tangara 1:57-73.

Höfling, E., and H. F. A. Camargo. 1993. Aves no Campus. São Paulo. Instituto de Biociências da Universidade de São Paulo.

Justino, D. G., P. K. Maruyama, and P. E. Oliveira. 2012. Floral resource availability and hummingbird territorial behaviour on a Neotropical savanna shrub. Journal of Ornithology 153:189-197. https://doi.org/10.1007/s10336-0110726-x.

Leveau, L. M. 2013. Bird traits in urban-rural gradients: how many functional groups are there? Journal of Ornithology 154:655-662. https://doi.org/10.1007/s10336-012-0928-x.

Lowe, E. C., C. G. Threlfall, S. M. Wilder, and D. F. Hochuli. 2018. Environmental drivers of spider community composition at multiple scales along an urban gradient. Biodiversity and Conservation. 27:829-852. https://doi.org/ 10.1007/s10531-017-1466-x.

Marini, M. A., and F. I. Garcia. 2005. Conservação de aves no Brasil. Megadiversidade 1:95-102.

Maruyama, P. K., C. Bonizário, A. P. Marcon, G. D’Angelo, M. M. Silva, E. N. S. Neto, P. E. Oliveira, I. Sazima, M. Sazima, J. Vizentin-Bugoni, L. Anjos, A. M. Rui, and O. Marçal Jr. 2019.Plant-hummingbird interaction networks in urban areas: Generalization and the importance of trees with specialized flowers as a nectar resource for pollinator conservation. Biological conservation 230:187-194. https://doi.org/10.1016/j.biocon.2018.12.012.

Marzluff, J., and K. Ewing. 2001. Restoration of fragmented landscapes for the conservation for urbanizing landscapes. Restoration Ecology 9:280-292. https://doi.org/10.1046/j.1526-100x.2001.009003280.x.

Matarazzo-Neuberger, W. M. 1990. Aves de uma seção de mata atlântica, Santo André, SP. Anais do Simpósio de ecossistemas da costa sul e sudeste brasileira. São Paulo. ACIESP 1:385-394.

Matias, R., P. K. Maruyama, and H. Consolaro. 2016. A non-hermit hummingbird as main pollinator for ornithophilous plants in two isolated forest fragments of the Cerrados. Plant Systematics and Evolution 302:1217-1226. https://doi.org/ 10.1007/s00606-016-1327-1.

McKinney, M. 2002. Ubanization, biodiversity and conservation. Bioscience 52:883-890. https://doi.org/10.1641/00063568(2002)052[0883:UBAC]2.0.CO;2.

Meira, N. T. 2016. Fatores que influenciam a presença de Tangara cayana e Taraba major na região oeste do Estado de São Paulo, Brasil. Dissertação. Mestrado em Biociências: Caracterização e Aplicação da Diversidade Biológica. Universidade Estadual Paulista, Assis, São Paulo, Brasil. Pp. 45. 
Mendonça, L. B., and L. Anjos. 2005. Beija-flores (Aves, Trochilidae) e seus recursos florais em uma área urbana do Sul do Brasil. Revista Brasileira de Zoologia 22:51-59. https://doi.org/10.1590/S0101-81752005000100007.

Mekonen, S. 2017. Birds as biodiversity and environmental indicator. Journal of Natural Sciences Research 7:28-33.

Monteiro, V. L. C. 2018. Composição de espécies dos grupos funcionais da avifauna nas matas ciliares urbanas. Monografia. Bacharel em Ciências Biológicas. Universidade de Taubaté, São Paulo, Brasil. Pp. 39.

Moran, A. J., S. W. J. Prosser, and J. A. Moran. 2019. DNA metabarcoding allows non-invasive identification of arthropod prey provisioned to nestling Rufous hummingbirds (Selasphorus rufus). PeerJ 7:e6596. https://doi.org/ 10.7717/peerj.6596.

Naime, R. 2011. Animais Bioindicadores. EcoDebate. Índice de edição: 1335.

Nguyen, H. M. 2007. Bird composition as na ecological indicator of forest disturbance levels. PhD tesis. Departament School of Biological Sciences, University of Texas, Austin. USA. Pp. 39.

Puga-Caballero, A., M. D. C. Arizmendi, and L. A. Sánchez-González. 2020. Phylogenetic and phenotypic filtering in hummingbirds from urban environments in Central Mexico. Evolutionary Ecology 34:525-541. https://doi.org/ 10.1007/s10682-020-10055-z.

Ricklefs, R., and R. Relyea. 2018. Economia da Natureza. Seventh edition. Guanabara Koogan. Rio de Janeiro, Rio de Janeiro, Brasil.

Sacco, A. G., A. M. Rui, F. B. Bergmann, S. C. Müller, and S. M. Hartz. 2015. Perda da diversidade taxonômica e funcional de aves em área urbana no sul do Brasil. Iheringia, Série Zoologia 3:276-287. https://doi.org/10.1590/1678476620151053276287.

Santos, J. S. 2014. Influência da permeabilidade da matriz e da heterogeneidade da paisagem na conservação da biodiversidade de mamíferos terrestres. PhD tesis. Instituto Nacional de Pesquisas Espaciais, São Paulo, Brasil.

Scherer, A., F. Maraschin-Silva, and L. R. M. Baptista. 2007. Padrões de interações mutualísticas entre espécies arbóreas e aves frugívoras em uma comunidade de Restinga no Parque Estadual de Itapuã, RS, Brasil. Acta Botanica Brasilica 21:203-2012. https://doi.org/10.1590/S0102-33062007000100019.

Sick, H. 1997. Ornitologia brasileira. Second edition. Nova Fronteira, Rio de Janeiro, Brasil.

Silva, W. R., P. de Marco-Jr. Hasui, and V. S. M, Gomes. 2002. Patterns of fruit-frugivore interactions in two Atlantic Forest Bird communities of South-eastern Brazil: Implications for conservation. In D. J. Levey, W. R. Silva and M. Galetti (eds.). Seed dispersal and frugivory: ecology, Evolution and conservation. New York, CAB International. https://doi.org/10.1079/9780851995250.0423.

Silva, G. A. V. 2010. Manual de avaliação e monitoramento de integridade ecológica, com uso de bioindicadores e ecologia de paisagens. Mestrado em Conservação e Sustentabilidade. Escola Superior de Conservação Ambiental e Sustentabilidade, São Paulo. Brasil. Pp. 75.

Silva, F. C., G. G. Silva, M. O. Chagas, and D. M. H. Jung. 2014. Composição da comunidade de aves em área urbana no sul do Brasil. Neotropical Biology and Conservation 9(2). https://doi.org/10.4013/nbc.2014.92.02.

Silva, C. P., R. D. Sepúlveda, and O. Barbosa. 2016. Nonrandon filtering effect on birds: species and guilds response to urbanization. Ecology and Evolution 6:3711-3720. https://doi.org/10.1002/ece3.2144.

Sol, D., C. Gonzáles-Lagos, D. Moreira, J. Maspons, and O. Lapiedra. 2014. Urbanisation tolerance and the loss of avian diversity. Ecology Letters 17:942-950. https://doi.org/10.1111/ele.12297.

Stiles, F. G. 1981. Geographical aspects of birds-flower coevolution, with particular reference to Central América. Annals of the Missouri Botanical Garden 68:323-351. https://doi.org/10.2307/2398801.

Steinitz, O., J. Heller, A. Tsoar, D. Rotem, and R. Kadmon. Environment, dispersal and patterns of species similarity. 2006. Journal of Biogeography 33:1044-1054. https://doi.org/10.1111/j.1365-2699.2006.01473.x.

Tella, J. L., F. Hiraldo, E. Pacífico, J. A. Días-Luque, F. V. Dénes, F. M Fontoura, N. Guedes, and G. Blanco. 2020. Conserving the Diversity of Ecological Interactions: the role of two threatened macaw species as legitimate dispersers of "megafaunal" fruits. Diversity 12:45. https://doi.org/10.3390/d12020045.

Toledo, M. C. B., and D. M. Moreira. 2008. Analysis of the feeding habitats of the swallow - tailed hummingbird, Euptomena macroura (Gmelin, 1788), in na urban park in southeastern Brazil. Brazilian Journal of Biology 68:419-426. https://doi.org/10.1590/S1519-69842008000200027.

Toledo, M. C. B., R. J. Donatelli, and G. T. Batista. 2012. Relation between green spaces and bird community structure in an urban area in Southeast Brazil. Urban Ecosystems 15:111-131. https://doi.org/10.1007/s11252-011-0195-2.

Uezu, A., J. P. Metzger, and J. M. 2005. Vielliard. Effects of structural and functional connectivity and patch size on the abundance of seven Atlantic Forest bird species. Biological conservation 123:507-519. https://doi.org/10.1016/ j.biocon.2005.01.001.

Willis, E. O., and Y. Oniki. 2003. Aves do Estado de São Paulo. First edition. Divisa. Rio Claro, Brasil. 